\title{
ASPEK HUKUM PENANAMAN MODAL PERIKANAN TANGKAP TERPADU ZONA EKONOMI EKSKLUSIF INDONESIA (ZEEI) \\ BERDASARKAN PERMEN KP NO. 30 TAHUN 2012
}

\author{
Danang Hardianto*, Paramita Prananingtyas** \\ Program Studi Magister IImu Hukum \\ Fakultas Hukum Universitas Diponegoro \\ pptyas@yahoo.com
}

\begin{abstract}
ABSTRAK
ZEEI ialah wilayah dengan batas terluar 200 (dua ratus) mil laut yang memiliki potensi sumber daya ikan untuk dikelola dalam sistem bisnis perikanan yaitu menekankan penangkapan, pengolahan, produksi dan pemasaran. Pengaturan usaha perikanan tangkap terpadu ZEEI dalam sistem bisnis perikanan dapat dipadukan dengan kawasan berikat dan minapolitan Pola hukum investasi industri ini ialah pola-kerjasama, pola sewa beli dan pola lisensi. Industri ini dapat merangsang investor asing dan nasional serta memperdayakan masyarakat. Industri dapat menjadi industri pionir tertutama ditujukan kawasan pesisir di Wilayah Indonesia Timur sehingga terwujudkan kesejahteraan masyarakat dan industri perikanan yang berbasis kedaulatan (sovereignty), keberlanjutan (sustainability) dan kemakmuran (prosperity).
\end{abstract}

Kata Kunci: Penanaman Modal; Perikanan; ZEE I

\footnotetext{
* Mahasiswa Program Studi Magister Ilmu Hukum UNDIP

${ }^{*}$ Penulis Kedua, Penulis Koresponden
} 


\section{A. PENDAHULUAN}

\section{Latar Belakang}

Pengelolaan sumber daya alam (SDA) merupakan amanah konstitusi, khususnya Pasal 33 ayat (3) Undang-Undang Dasar 1945 (UUD 1945). Pasal ini menekankan pengelolaan SDA yang termasuk dikandung di dalamnya dikuasai oleh negara dan dipergunakan untuk sebesar-besar kemakmuran rakyat. Salah satu SDA ialah Zona Ekonomi Eksklusif Indonesia (ZEEI) dengan batas 200 (dua ratus) mil laut yang diukur dari garis pangkal laut teritorial Indonesia.

Dengan wilayah laut seluas 58 juta $\mathrm{km}^{2}$, Indonesia menjadi salah satu negara yang memiliki keanekaragaman hayati dan non hayati kelautan terbesar di dunia. ${ }^{1}$ Menurut Sunaryati Hartono keanekaragaman tersebut harus dipetakan, diungkap dan ditingkatkan menjadi potensi strategis bagi pembangunan dan perencanaan sumber daya kelautan. ${ }^{2}$ Sumber daya Ikan (SDI) menjadi salah satu andalan potensi kelautan dan perikanan.

1 Kementerian Kelautan dan Perikanan Republik Indonesia (KKPRI), 2010, Pokok Kelautan dan Perikanan Tahun 2010, Jakarta, Pusat Statistik Koordinasi dan Penanaman Modal Kemennterian Dalam Negeri Lembaga IImu Pengetahuan Indonesia, hlm. 3.

2 Badan Pembinaan Hukum Nasional, 1993-1994, Laporan Penelitian Tentang Aspek-Aspek Hukum Pengelolaan Perikanan di Perairan Nasional Zona Ekonomi Eksklusif Indonesia, Dibawah Pimpinan: H.A.S. Natabaya, Jakarta, Badan Pembinaan Hukum Nasional Departemen Kehakiman, hlm. 3.
Pertumbuhan produksi perikanan setiap tahun mencapai $7 \%$ per tahun. Untuk gross domestic product (GDP), sektor perikanan mengalami pertumbuhan positif sekitar 5,2 \% ekonomi nasional. 3 Oleh karena itu, ZEEI memiliki potensi SDI sangat besar untuk dikelola dalam industri perikanan dengan cara yang tepat, terarah dan bijaksana untuk peningkatan kesejahteran masyarakat.

Pengolaan industri perikanan ZEEI saat ini belum maksimal dikelola sesuai dengan sistem bisnis perikanan Indonesia. Permasalahan di zona ini misalnya illegal fishing, illegal licensing, dan transshipment. Illegal Fishing dikenal dengan istilah Illegal, Unregulated, and Unreported Fishing (IUU-Fishing), yaitu penangkapan ikan dilakukan secara illegal, tidak dilaporkan dan tidak sesuai dengan aturan yang berlaku. ${ }^{4}$ Meskipun terdapat permasalan bukan bukan berarti mendiscourage untuk tidak melakukan investasi di bidang ini. Peluang investasi di industri perikanan tetap terbuka lebar bagi investor asing dan nasional sebagai pelaku usaha industri perikanan untuk bersaing mengelola di

3 Badan Koordinasi Penanan Modal (BKPM), Fisheries Industry at Glance, lihat website: www.bkpm.go.id, diakses 11 Agustus 2015.

${ }^{4}$ Dina Sunyowati, Dampak Kegiatan IUU-F ishing Di Indonesia, Disampaikan pada Seminar Nasional "Peran dan Upaya Penegak Hukum dan Pemangku Kepentingan Dalam Penanganan dan Pemberantasan IUU Fishing di Wilayah Perbatasan Indonesia". Kerjasama Kementerian Luar Negeri Republik Indonesia dengan Universitas Airlangga Surabaya, 22 September 2014, hlm. 2-3. 
zona ekonomi laut ini. ${ }^{5}$ Oleh sebab itu, merujuk pendapat Akhmad Solihin, perlu adanya cara untuk menciptakan kelancaran pelaksanaan kebijakan, ${ }^{6}$ khususnya industri perikanan terpadu ZEEI.

Berpangkal dari uraian di atas yang diangkat menjadi isu hukum, maka judul penelitian tesis ini ialah "Aspek Hukum Penanaman Modal Perikanan Tangkap Terpadu Zona Ekonomi Eksklusif Indonesia (ZEEI) Berdasarkan Permen KP No. 30 Tahun 2012".

Untuk menganalisis dan memecahkan isu hukum di atas, maka dalam penelitian ini diperinci secara mendalam ke dalam dua sub rumusan masalah, meliputi:

1. Pengaturan usaha perikanan tangkap terpadu ZEEI dalam sistem bisnis perikanan.

2. Aspek hukum penanaman modal industri perikanan tangkap terpadu ZEEI dalam sistem bisnis perikanan.

\section{Metode Penelitian}

Metode penelitian yang digunakan dalam penelitian ini ialah yuridis-normatif yaitu suatu proses untuk menemukan aturan-aturan

\footnotetext{
5 Kiara Bakal Kawal Komitmen Kelautan Presiden Jokowi, http://sumbar.antaranews.com/, diakses 11 Agustus 2015.

${ }^{6}$ Akhmad Solihin, 2010, Politik Hukum Kelautan \& Perikanan Isu, Permasalahan, dan Telaah Kritis Kebijakan, Bandung, Nuasa Aulia, hlm. 71.
}

hukum, prinsip-prinsip hukum, maupun doktrindoktrin hukum guna menjawab isu hukum yang dihadapi. ${ }^{7}$

\section{Kerangka Teori}

Sumber kekayaan perikanan Indonesia ialah salah satu sumber daya (prime mover) ekonomi nasional. Menurut Daryanto, kenyataan tersebut didasarkan beberapa alasan: pertama, Indonesia memiliki sumber daya perikanan yang besar baik ditinjau dari kuantitas maupun diversitas; kedua, industri di sektor perikanan memiliki keterkaitan dengan sektor-sektor lainnya; ketiga, industri perikanan berbasis sumber daya nasional atau dikenal istilah national resources based industries; dan terakhir, Indonesia memiliki keunggulan (comparative advantage) yang tinggi di sektor perikanan sebagaimana dicerminkan dari potensi sumber daya yang ada. ${ }^{8}$

Tiga opsi yang dilakukan oleh Departemen Kelautan dan Perikanan (DKP) yaitu pola kerja sama, pola sewa-beli, dan pola lisensi, yang ditawarkan kepada perusahaan perikanan internasional. Menurut Rokhmin Dahuri, ketiga pola itu dapat dikembangkan rantai industri

7 Peter Mahmud Marzuki, 2013, Penelitian Hukum, Edisi Revisi, Jakarta, Kencana Prenada Media Group, hlm. 133-134.

8 Ramlan, 2015, Konsep Hukum Tata Kelola Perikanan Perlindungan Hukum Industri Perikanan dari Penanaman Modal Asing di Indonesia, Malang, Setara Press, hlm. 4-5. 
perikanan yang utuh dan kokoh, mulai dari penangkapan, pengolahan dan pemasarannya, serta membuka kesempatan bagi nelayannelayan Indonesia menjadi nelayan-nelayan modern, berpengetahuan, serta menguasai teknologi. ${ }^{9}$

\section{B. HASIL DAN PEMBAHASAN}

1. Pengaturan Usaha Perikanan Tangkap

\section{Terpadu ZEEI Dalam Sistem Bisnis Perikanan}

ZEEI adalah jalur di luar dan berbatasan dengan laut teritorial Indonesia yang meliputi dasar laut, tanah di bawahnya, dan air di atasnya dengan batas terluar 200 (dua ratus) mil laut yang diukur dari garis pangkal laut teritorial Indonesia. Zona ini disebut sui generis. Merujuk pendapat dari James Kraska, negara pantai termasuk Indonesia memiliki hak penggunaan secara ekonomis (economic utilization), salah satunya pengelolaan perikanan. ${ }^{10}$ Pengelolaan perikanan terlepas dari doktrin liberum mare yang mana doktrin ini hanya berlaku di laut lepas yang tidak mengenal adanya batasan penangkapan ikan. ${ }^{11}$ Pengelolaan ikan di ZEEI merupakan

9 Indroyono Soesilo dan Budiman, 2006, IPTEK Menguak Laut Indonesia, Bogor, Sarana Komunikasi Utama (SKU), hlm. 71-72.

10 James Kraska, 2011, Maritime Power and The Law of The Sea Expeditionary Operations In World Politics, New York, Oxford University Press, hlm. 142.

11 Tore Henriksen, et.al, 2006, Law and Politics in Ocean Governance The UN Fish Stocks Agreement and kewajiban pemerintah untuk menentukan batasan jumlah tangkapan yang diperbolehkan sehingga SDA ini dapat lestari dan berkelanjutan (sustainable). ZEEI seyogianya tidak dianggap sebagai open acces atau hampir tidak ada batasan untuk melakukan akses eksploitasi terhadap SDI atau tidak yang termasuk rezim non property. Dengan kata lain, ZEEI adalah hak mutlak Indonesia untuk mengelolanya tanpa mengesamping perjanjian dan ketentuan hukum Internasional. Salah satunya ialah memberikan peluang kepada pelaku usaha nasional atau asing untuk memanfaatkannya sesuai ketentuan yang dibuat oleh Indonesia. ${ }^{12}$

Produk hasil industri perikanan diwajibkan memenuhi persyaratan berupa kelayakan pelolaan ikan, sistem jaminan mutu dan keamanan hasil perikanan. Sistem ini berupa pengawasan dan pengendalian mutu; pengembangan dan penerapan persyaratan atau standar bahan baku, persyaratan dan standar sanitasi dan teknik penanganan serta pengolahan, persyaratan atau standar mutu produk, persyaratan atau standar sarana dan prasarana, serta persyaratan atau standar metode pengujian; dan sertifikasi.

Regional Fisheries Management Regimes, Martinus Nijhoff Publishers, Leiden / Boston, hlm. 2.

12 P. Joko Subagyo, 2009, Hukum Laut Indonesia, Rineka Cipta, Jakarta, hlm. 71-72. 
Merujuk pendapat Aji Soelarso, bahwa pengelolaan perikanan (fisheries management) merupkan hal yang kompleks, tetapi bukan berarti menjadi suatu hal yang tidak mungkin untuk dilakukan oleh pemerintah sebagai pengambil kebijakan dengan bukan hanya bertumpu pada ketentuan hukum nasional melainkan pula internasional agar produk perikanan Indonesia dapat berdaya saing di pasar internasional untuk meningkatkan pendapatan devisa bagi negara. ${ }^{13}$ Ajo sularso mengkritisi kebijakan saat ini. Dia menyarankan agar diperbaiki manajemen pengelolaan dengan menerapkan sistem industri cluster atau kawasan industri perikanan. Intinya sistem industri ini adalah merubah paradigma lama dan konvensional dari manajemen yang terpisah antara pemberian izin penangkapan dengan industri menjadi manajemen yang terintegrasi hulu ke hilir. ${ }^{14}$

Setiap pelaku usaha perikanan di bidang penangkapan, pembudidayaan, pengolahan, pengangkutan, pengolahan dan pemasaran ikan di WPPRI wajib memiliki SIUP.15 Izin ini tidak berlaku bagi nelayan kecil dan/atau

13 Aji Sularso, http://ajisularso.com/industriperikanan-berbasis-clusterl, diakses 7 November 2015.

14 Ibid.

15 Pasal 26 ayat UU Perikanan 2004 (1) jo Pasal 1 angka 16 UU Perikanan 2009. Surat Izin usaha perikanan, yang selanjutnya disebut SIUP, adalah izin tertulis yang harus dimiliki perusahaan perikanan untuk melakukan usaha perikanan dengan menggunakan sarana produksi yang tercantum dalam izin tersebut. pembudi daya ikan kecil. ${ }^{16}$ Di samping SIUP, setiap orang wajib memiliki dan/atau mengoperasikan kapal penangkap ikan berbendera Indonesia/asing yang dipergunakan untuk melakukan penangkapan ikan di WPPRI dan/atau laut lepas wajib memiliki SIPI. ${ }^{17}$ Izin ini dikeluarkan oleh Menteri Kelautan dan Perikanan. ${ }^{18}$ Selanjutnya, adapun izin selain SIUP dan SIPI yang harus dipenuhi yaitu SIKPI diterbitkan olen Menteri Kelautan dan Perikanan untuk mengoperasikan kapal pengangkut Ikan di WPPRI. ${ }^{19}$

Syarat-syarat memperoleh SIUP bagi perusahaan perikanan tangkap di WPPRI diatur dalam Pasal 11-13 Permen KP No. 30 Tahun 2012. Izin usaha perikanan tangkap, meliputi: a. izin usaha perikanan yang diterbitkan dalam bentuk SIUP; b. izin penangkapan ikan yang diterbitkan dalam bentuk SIPI; dan c. izin kapal pengangkut ikan yang diterbitkan dalam bentuk SIKPI. SIUP terdiri dari: a. SIUP perorangan; $b$. SIUP perusahaan; dan c. SIUP penanaman modal. Untuk kapal penangkap ikan dalam

16 Pasal 26 ayat (2) UU Perikanan 2004.

17 Pasal 27 ayat (1) UU Perikanan 2004 dan (2) jo Pasal 1 angka 17 UU Perikanan 2009. Surat izin penangkapan ikan, yang selanjutnya di sebut SIPI, adalah izin tertulis yang harus dimiliki setiap kapal perikanan untuk melakukan penangkapan ikan yang merupakan bagian tidak terpisahkan dari SIUP.

18 Pasal 27 ayat (3) UU Perikanan 2009.

19 Pasal 28 ayat (1) UU Perikanan 2009 dan (2) jo Pasal 1 angka 18 UU Perikanan 2004. Surat izin kapal pengangkut ikan, yang selanjutnya disebut SIKPI, adalah izin tertulis yang harus dimiliki setiap kapal perikanan untuk melakukan penangkapan ikan. 
usaha perikanan tangkap terpadu ditambah persyaratan berupa surat keterangan dari Direktur Jenderal Pengolahan dan Pemasaran Hasil Perikanan yang menyatakan: a) realisasi pembangunan Unit Pengolahan Ikan (UPI) paling sedikit 75\% (tujuh puluh lima persen), untuk pengadaan kapal penangkap ikan bekas; b)realisasi pembangunan Unit Pengolahan Ikan (UPI) paling sedikit 50\% (lima puluh persen), untuk pengadaan kapal penangkap ikan baru; atau c) realisasi pembangunan Unit Pengolahan Ikan (UPI) paling sedikit 65\% (enam puluh lima persen), untuk pengadaan kapal penangkap ikan dalam keadaan baru dan bekas.

Pada tahun 2010 KKP membangun recana strategi dengan konsep kawasan minapolitan yang diatur dalam Permen KP. No. 12 Tahun 2010 tentang Minapolitan. Pengembangan kawasan minapolitan dilakukan secara terintegrasi, efisien, dan berkualitas serta mendorong percepatan peningkatan produksi, pengolahan dan/atau pemasaran. Pengembangan kawasan minapolitan dimulai dari pembinaan unit produksi, pengolahan, dan/atau pemasaran yang terkonsentrasi di sentra produksi, pengolahan dan/atau pemasaran di suatu kawasan yang diproyeksikan atau direncanakan menjadi kawasan minapolitan yang dikelola secara terpadu. ${ }^{20}$

Pemilihan kawasan minapolitan dilakukan secara terkoordinasi antara pemerintah, pemerintah provinsi, dan pemerintah kabupaten/kota. Menurut H. Djoko Tribawono, perkembangan minapolitan harus dilakukan dengan pendekatan: a) Ekonomi kelautan dan perikanan berbasis wilayah; b) Kawasan ekonomi unggulan; c) Sentra produksi; d) Unit usaha; e) Penyuluhan; dan f) Lintas sektor. ${ }^{21}$ Sedangkan, menurut Thomas Farole et al kebijakan pendirian kawasan berikat dibangun dengan empat tujuan, antara lain: a) Untuk menarik penanaman modal langsung (foreign direct investment/FDI; b) memberikan pelayanan sebagai katup tekanan (pressure valves) yang bertujuan untuk menekan angka pengangguran secara besar-besaran; c) Untuk mendukung strategi reformasi ekonomi yang lebih luas. Kawasan berikat adalah alat sederhana yang memungkinkan suatu negara untuk mengembangkan dan memversifikasi ekspor. Kawasan juga dapat mengurangi ketidakjelasan program anti-ekspor sekaligus mendukung program perlindungan barang ekspor; dan d) Sebagai laboratorium eksperimental untuk penerapan kebijakan dan

\footnotetext{
20 Pasal 5 Permen KP. No. 12 Tahun 2010.

21 H. Djoko Tribawono, 2013, Hukum Perikanan Indonesia, Edisi Revisi, Bandung,Citra Aditya Bhakti,
} hlm. 37. 
pendekatan baru. FDI, hukum, tanah, tenaga kerja, dan bahkan kebijakan penentuan harga diatur dan diuji untuk pertama kali dalam kawasan ini sebelum diperluas ke seluruh perekonomian nasional. ${ }^{22}$

Sudah barang tentu dapat dikemukakan pula bahwa industri perikanan terpadu ZEEI dapat dikolaborasikan dengan konsep kawasan berikat and minapolitan. Sehingga menjadi kawasan berikat minapolitan industri perikanan terpadu ZEEI dengan konsep sebagai berikut:

1) Pelabuhan atau dermaga khusus kapal perikanan ZEEI diatas 30 (tiga puluh) GT investor nasional atau asing, dengan ketentuan menggunakan kapal perikanan berukuran diatas 100 GT untuk investor asing; Bengkel dan docking kapal perikanan ZEEI;

2) Industri pengolahan ikan dengan kelengkapan cold storage, pabrik es dan pabrikasi pengalengan serta frozen fish untuk kepentingan pasar global;

3) Memperkokoh dan mengembangkan tol laut (konektivitas dan logistik maritim) berupa revitalisasi dan pembangunan armada baru kapal nasional dan internasional bukan hanya eksport ikan melainkan pula berdekatan dengan pelabuhan barang dan penumpang; dan fasilitas pendukung lainnya seperti penyediaan air bersih, BBM dan lain sebagainya; 23

22 Thomas Farole, et.al, 2011,Special Economic Zones Progress, Emerging Challenges, and Future Directions, World Bank, Washington DC, hlm. 3-4.

23 Bandingkan, http://www.kompasiana.com/rokhmin/pengembangankawasan-pertumbuhan-ekonomi-baru-berbasis-kelautandi-mamuju-utara 54f96a07a3331177578b45c1, diakses 7 November 2015.
4) Pembangunan pusat-pusat pertumbuhan ekonomi baru di sepanjang wilayah pesisir ALKI (Air Laut Kepulauan Indonesia), pulau-pulau kecil dan wilayah perbatasan; 24

5) Untuk menarik penanaman modal langsung (foreign direct investment/FDI dari asing dalam bentuk PT;

6) Pemberian izin penangkapan terpadu ZEEI dalam satu cluster kepada PMA dan PMDN dalam kurun waktu tertentu misalnya minimal 10 tahun;

7) Fasilitas pajak penghasilan perusahaan sesuai dengan ketentuan yang berlaku. Pengurangan pajak bumi dan bangunan untuk jangka waktu tertentu.Permohonan penundaan pajak import. Pembasan cukai untuk bahan baku mentah dan pendukung untuk produksi. Tidak dipungut Pajak pertambahan nilai dan pajak barang mewah. tidak dipungut pajak penghasilan perusahaan untuk impor; Pembebasan atau pengurangan pajak daerah dan/atau retribusi; tidak dipungut Pajak pertambahan nilai dan pajak barang mewah sesuai dengan ketentuan yang berlaku untuk pengiriman barang kena pajak untuk Kawasan Berikat dari daerah pabean Indonesia. 25

8) Komposisi tenanga kerja dalam industri ini $70 \%$ tenaga kerja Indonesia dan 30 $\%$ tenaga kerja asing termasuk anak buah kapal penangkapan ikan bagi perusahaan PMA baik kapal penangkap, pengangkut, produksi dan pemasaran dalam satu bisnis perikanan;

9) Fasilitas permodalan dari lembaga keuangan negeri yaitu bank daerah dan swasta dengan bunga ringan bagi unit

$24 \mathrm{lbid}$.

25 Bandingkan, Cf, HSBC, 2012, Doing Businees in Indonesia, Jakarta, HSBC Indonesia, hal. 14-15. 
usaha mikro, kecil dan menengah serta koperasi nelayan-nelayan, dan nelayannelayan perorangan penangkap dan pengangkut ikan untuk mendukung ketersedian bahan pengolahan dan produksi Industri ZEEI.

Konsep sistem bisnis di atas telah sesuai dengan ketentuan Pasal 9 Permen KP No. 30 Tahun 2012 yang mengintegrasikan kegiatan penangkapan ikan, pengangkutan ikan, pengolahan ikan dan pemasaran ikan. Integrasi ini ditujukan untuk meningkatkan mutu, nilai tambah, dan daya saing produk perikanan Indonesia.

\section{Aspek Hukum Penanaman Modal Industri} Perikanan Tangkap Terpadu ZEEI Dalam

\section{Sistem Bisnis Perikanan}

Permen KP No. 30 Tahun 2012 jo. Permen KP No. 26 Tahun 2013, Kedua permen ini mengatur investor untuk permohonan perizinan pendirian perusahaan melalui Alokasi Penangkap Ikan Penanam Modal (APIPM) kepada Direktur Jenderal melalui instansi yang berwenang di bidang penanaman modal yaitu Badan Koordinasi Penanaman Modal (BKPM). Permohonan perizinan wajib melampirkan persyaratan antara lain identitas perusahaan, untuk penanaman modal asing wajib mendirikan perseroan terbatas berdasarkan hukum Indonesia dan berkedudukan di dalam wilayah Negara Republik Indonesia dan rencana usaha antara lain rencana investasi, rencana kapal, dan rencana operasional. Direktur Jenderal menerbitkan APIPM apabila : a) telah memenuhi persyaratan sebagaimana ditetapkan; b) telah mempertimbangkan ketersediaan daya dukung sumber daya ikan; c) telah mempertimbangkan kelayakan rencana usaha yang diajukan; dan d) Pemohon telah membayar Pungutan Pengusahaan Perikanan (PPP) yang dibuktikan dengan tanda bukti pembayaran.

Rencana operasional yaitu pendaratan ikan dan pelabuhan pangkalan. Ikan hasil tangkapan dari kapal penangkap ikan dan/atau kapal pengangkut ikan dalam rangka PMA dan PMDN wajib didaratkan di pelabuhan pangkalan yang ditetapkan dalam SIPI dan/atau SIKPI. Ikan dari kapal penangkap ikan dan/atau kapal pengangkut ikan dalam rangka usaha perikanan tangkap terpadu wajib diproses pada UPI. Hasil pengolahan seluruhnya atau sebagian dapat diekspor sesuai dengan peraturan perundang-undangan yang berlaku. Pengecualian terhadap ikan hidup yaitu ikan yang telah mendapat penanganan di atas kapal, dan/atau ikan yang menurut sifatnya tidak memerlukan proses pengolahan. Ikan hasil tangkapan wajib dilaporkan kepada petugas di pelabuhan pangkalan sebagaimana tercantum di dalam SIPI dan/atau SIKPI. 
Investasi perikanan tangkap terpadu ZEEI dapat dilakukan dengan pola antara lain pola kerja sama atau usaha patungan (joint venture), pola sewa-beli atau beli angsur (purchase on installment), dan pola lisensi, yang ditawarkan kepada perusahaan perikanan internasional sebagaimana dikemukakan oleh Rokhmin Dahuri, namun juga tidak menutup kemungkinan pelaku usaha nasional untuk menanamkan modal mereka. ${ }^{26}$ Salah satu yang menghambat industri perikanan tangkap yaitu masalah permodalan terutama bagi nelayan skala kecil. Pola ini diharapkan kesejahteraan nelayan meningkat dengan cara kemintraan. ${ }^{27}$ Pola hukum perikanan terpadu ZEEI diatur dalam Keputusan Menteri Kelautan dan Perikanan Nomor : KEP.60/MEN/2001 Tentang Penataan Penggunaan Kapal Perikanan Di Zona Ekonomi Eksklusif Indonesia (Kepmen KP No. 60 Tahun 2001).

Berikut ini penjelasan dari penataan industri perikanan tangkap terpadu ZEEI dalam sistem bisnis perikanan.

26 Indroyono Soesilo dan Budiman, Loc.cit;; Badan Pembinaan Hukum Nasional (BPHN), 2012, Pengkajian Hukum Tentang Perlindungan Nelayan Tradisional Dalam Pengelolaan Sumber Daya Kelautan, Disusun Oleh Tim Di bawah Pimpinan Dr. Arif Satria, S.P., M.Si., Editor Theodrik Simorangkir, Jakarta, Badan Pembinaan Hukum Nasional Kementerian Hukum dan Hak Asasi Manusia RI, hlm. 35.

27http://bappenas.go.id/files/5214/4401/3139/8 Bab 6 Isu Strategis Dan Permasalahannya.pdf6-7, diakses 12 November 2015.

\section{1) Pola Kerja-sama}

Penataan industri perikanan terpadu ZEEI yang pertama ialah pola kerja sama atau usaha patungan antara pengusaha asing dan Indonesia. Pola ini ditegaskan dalam frase kalimat Pasal 1 angka 3 UU No. 25 Tahun 2007 tentang Penanaman Modal (UUPM) yaitu "yang dilakukan oleh penanam modal asing, yang berpatungan dengan penanam modal dalam negeri". Namun demikian, joint venture bukan merupakan keharusan bagi investor asing untuk bekerjasama dengan investor nasional. Pada ghalibnya, ketentuan tersebut merupakan bentuk dorongan dari pemerintah bagi kerjasama antara investor asing dan nasional atau pemerintah sendiri dengan insentif dan fasilitas berupa pembebasan pajak perusahaan dan pajak keuntungan. ${ }^{28}$ Menurut $M$. Sornarajah, insentif pajak ialah suatu cara yang efektif untuk menjamin investor asing menamankan modalnya sesuai dengan ketentuan yang berlaku sesuai dengan harapan pemerintah tuan rumah. Misalkan pembelian peralatan modern dan canggih yang dapat mendukung produksi perusahaan investor asing dengan memberikan keringanan atau pembebasan pajak. ${ }^{29}$

28 Erman Rajagukguk, 1985, Indonesianisasi Saham, Jakarta, Bina Aksara, hlm. 11.

29 M. Sornarajah, 2010, The International Law On Foreign Investment, Third Edition, New York, Cambridge University Press, hlm. 103. 
Menurut Pasal 1 angka 22 Kepmen KP No. 60 Tahun 2001, Usaha Patungan atau joint venture adalah kerjasama antara perusahaan perikanan dengan orang atau badan hukum asing untuk membentuk Badan Hukum Indonesia sesuai dengan peraturan perundangundangan di bidang Penanaman Modal Asing. Badan hukum Indonesia baru berdasarkan ketentuan yang berlaku di Indonesia sesuai dengan ketentuan UUPM yaitu PT.

Menurut Pasal 4 Kepmen KP No. 60 Tahun 2001, penataan penggunaan kapal perikanan dengan cara usaha patungan dilakukan dengan menjadikan kapal perikanan asing sebagai penyertaan modal pada perusahaan perikanan patungan sesuai dengan peraturan perundangundangan di bidang PMA. Perusahaan perikanan patungan dapat juga mengadakan kapal perikanan dengan cara beli-angsur. Perusahaan perikanan patungan yang akan mengadakan kapal perikanan wajib terlebih dahulu memperoleh persetujuan dari Direktur Jenderal dengan menyampaikan permohonan dengan melampirkan fotokopi surat persetujuan (SPT) penanaman modal. Perusahaan perikanan patungan di bidang penangkapan ikan yang mengoperasikan 20 (dua puluh) kapal penangkap ikan atau lebih wajib membangun UPI di darat minimal senilai 20\% (dua puluh persen) dari seluruh nilai kapal penangkap ikan yang dioperasikan. Pada perusahaan perikanan patungan, penyertaan modal pihak Indonesia untuk tahun pertama minimal 20\% (dua puluh persen) dari seluruh modal yang disetorkan/ditempatkan.

Nilai Kapal perikanan asing yang dimasukkan sebagai penyertaan modal dalam usaha patungan ditetapkan berdasarkan pertimbangan Tim Penilai yang ditunjuk oleh Direktur Jenderal. Kapal perikanan yang digunakan untuk menangkap ikan di ZEEI oleh perusahaan perikanan patungan wajib dilengkapi dengan Surat Penangkapan Ikan $(\mathrm{SPI})^{30}$ yang disampaikan kepada Direktur Jenderal dan sekurang-kurangnya memuat : a. Identitas pemohon; b. Jumlah SPI yang dimohonkan; c. Alat penangkap ikan yang akan digunakan dan daerah penangkapan serta pelabuhan pangkalan; dan d. Asal-usul kapal.

\footnotetext{
30 Berdasarkan Pasal 1 angka 20 Kepmen KP No. 60 Tahun 2001, Surat Penangkapan Ikan (SPI) adalah surat yang harus dimiliki setiap kapal perikanan berbendera Indonesia untuk melakukan kegiatan penangkapan ikan di perairan Indonesia dan/atau Zona Ekonomi Eksklusif Indonesia yang merupakan bagian yang tidak terpisahkan dari Izin Usaha Perikanan (IUP). Istilah SPI saat ini diganti dengan Surat Izin Penangkapan Ikan (SIPI) sebagaimana diatur dalam Pasal 1 angka 17 jo. Pasal 27 UUP 2009 yaitu izin tertulis setiap kapal perikanan untuk melakukan penangkapan ikan yang merupakan bagian tidak terpisahkan dari Surat Izin Usaha Perikanan (SIUP). Sementara IUP diganti dengan istilah SIUP dalam Pasal 1 angka 16 jo. 26 ayat (1) UUP 2004 ialah izin tertulis yang harus dimiliki perusahaan perikanan untuk melakukan usaha perikanan dengan menggunakan sarana produksi yang tercantum dalam izin tersebut.
} 


\section{2) Pola Sewa-Beli}

Berdasar Pasal 1 angka 5 Kepmen No. 60 Tahun 2001, Beli Angsur adalah transaksi pembelian kapal perikanan asing oleh perusahaan perikanan yang pembayarannya dilakukan dengan cara mengangsur dalam periode waktu tertentu dan dituangkan dalam perjanjian beli-angsur. Tridoyo Kusumastanto berpendapat bahwa pola sewa-beli atau sewa (charter) atau beli angsur (purchase on installment) adalah bentuk peluang bagi pengusaha nasional untuk dapat membeli kapal asing dengan cara mengangsur. Pada awalnya untuk komposisi tenaga kerja pada tahun pertama 50\% dari dalam negeri dan 50\% tenaga kerja asing, kemudian selanjutnya secara bertahap dikurangi 10\% setiap tahunnya sehingga dalam tahun keenam diharapkan 100\% tenaga kerja dalam negeri. Yang menjadi persoalan pola ini memiliki kelemahan perlindungan dan pengawasan serta sanksi yang dikenakan kepada pengguna kapal asing di ZEEI terhadap kelestarian SDI. ${ }^{31}$

Selanjutnya Pola di atas diganti sesuai dengan ketentuan Pasal 35A UUP 2009 untuk komposisi tenaga kerja. Kompisisnya berjumlah $70 \%$ tenaga kerja dalam negeri dan 30\% tenaga kerja asing. Komposisi penggunaan

31 Tridoyo Kusumastanto, Pemberdayaan Sumberdaya Kelautan, Perikanan Dan Perhubungan Laut Dalam Abad XXI, http://www.lfip.org/english/pdf, diakses 13 November 2015. tenaga kerja ini disesuaikan dengan ukuran kapal dan jenis alat tangkap yang akan digunakan di ZEEI. Kelemahan pola ini tetap sama yaitu pemerintah harus meningkatkan perlindungan, pengawasan dan sanksi yang tegas untuk tidak overcapitalization atau overfishiing di ZEEI. Berdasar data tingkat eksploitasi sumberdaya perikanan ZEEI yang sudah dilakukan selama ini, ternyata beberapa wilayah sudah mengalami eksploitasi secara berlebihan, seperti Selat Malaka dan Laut Arafura. Menurut Tridoyo Kusumastanto seyogianya kebijakan ini bukan hanya menduplikasi pola yang pertama sehingga hal ini berimplikasi menghancurkan SDI di ZEEI. Faktanya, pengusaha perikanan domestik yang menggunakan fasilitas semacam ini dimasa lalu hanya menjadi "mafia" yang di-becking oleh oknum militer dan kekuasaan. ${ }^{32}$ Untuk mengatasi hal tersebut, Rokhmin Dahuri menyarankan agar seyogianya dihentikan terlebih dahalu untuk ditata kembali melalui kebijakan baru. Kapal-kapal asing dicabut izinya dan dikembalikan menjadi berbendera asing sesuai negara asalnya. Jika pembenahan terhadap status kapal tersebut telah selesai dilaksanakan, selanjutnya direncanakan akan dibuka peluang kembali beroperasinya kapal ikan asing melalui salah satu mekanisme yang biasa berlaku secara internasional, yaitu pola

$$
32 \text { Ibid. }
$$


sewa-beli atau sewa (charter) atau beli angsur (purchase on installment). Kapal ikan tersebut nantinya hanya akan diizinkan beroperasi di perairan ZEEI, dalam jumlah terbatas dan menggunakan alat tangkap tertentu sesuai ketersediaan SDI di perairan tersebut. ${ }^{33}$ Lebih lanjut, Rokhmin Dahuri menjelaskan kapal asing tersebut hanyalah bersifat sementara sampai armada kita memang cukup kapasitas untuk memanfaatkan sumber daya ikan di ZEEI. Ini memang merupakan suatu hal yang tidak dapat dihindari, karena hal ini telah diatur dalam ketentuan Konvensi Hukum Laut 1982 yang menyatakan bahwa negara pantai harus menetapkan kemampuannya dalam memanfaatkan sumber kekayaan hayati di ZEE-nya. 34

Dengan pola sewa-beli diharapkan dapat memberikan peluang bagi pengusaha nasional untuk memiliki kapal-kapal yang memiliki peralatan canggih yang dioperasikan oleh tenaga kerja yang profesional, untuk selanjutnya terjadi transfer teknologi dan meningkatkan kemampuan $\mathrm{ABK}$ Indonesia menjadi lebih terampil. Hal sesuai dengan ketentuan Pasal 10 ayat (3) dan (4) Kepmen KP No. 60 Tahun 2001. Perusahaan penanaman modal wajib meningkatkan

33 Rokhmin Dahuri, Dibutuhkan Platform Pembangunan Ekonomi yang Berpihak ke Laut, http://perpustakaan.bappenaas.go.id, diakses 13 November 2015. 34 lbid. kompetensi tenaga kerja warga negara Indonesia melalui pelatihan kerja sesuai dengan ketentuan peraturan perundangundangan. Perusahaan penanaman modal yang mempekerjakan tenaga kerja asing diwajibkan menyelenggarakan pelatihan dan melakukan alih teknologi kepada tenaga kerja warga negara Indonesia sesuai dengan ketentuan peraturan perundang-undangan. Kepmen No. 60 Tahun 2001 mengatur penataan penggunaan kapal perikanan dengan cara beli-angsur dilakukan dengan memberi kesempatan kepada perusahaan perikanan untuk melakukan pengadaan kapal perikanan dengan cara beli-angsur kapal perikanan asing. Perusahaan perikanan yang akan melakukan pengadaan kapal perikanan dengan cara beliangsur wajib terlebih dahulu memperoleh persetujuan dari Direktur Jenderal. Untuk memperoleh persetujuan wajib menyampaikan permohonan kepada Direktur Jenderal dengan melampirkan: a. Salinan IUP; b. Rencana pengoperasian kapal; c. Rencana pembayaran angsuran. Persetujuan diberikan sesuai dengan ketersedian surplus JTB yaitu Jumlah Tangkapan Yang Diperbolehkan (JTB) adalah sisa JTB yang belum dimanfaatkan oleh perusahaan perikanan dalam kurun waktu tertentu.

Perusahaan perikanan yang telah memperoleh persetujuan wajib melaksanakan 
pengadaan kapal dengan perjanjian beli-angsur dibuat di hadapan Notaris dalam bahasa Indonesia dan bahasa Inggris. Perjanjian beliangsur sekurang-kurangnya memuat: a. Identitas para pihak; b. Spesifikasi teknis kapal yang diperjanjikan; c. Hak dan kewajiban para pihak; d. Tata cara pembayaran beli-angsur kapal dan pengalihan kepemilikan kapal; dan e. Jangka waktu beli-angsur.

Pembayaran kapal perikanan yang diperoleh dengan cara beli-angsur, wajib dilakukan dengan menggunakan jasa perbankan. Pengalihan kepemilikan atau penggantian bendera kapal perikanan menjadi kepemilikan orang atau badan hukum Indonesia dilakukan sesuai dengan peraturan perundang-undangan yang berlaku. Kapal perikanan yang diperoleh dengan cara beliangsur yang digunakan menangkap ikan di ZEEI, wajib dilengkapi dengan SPI. Surat permohonan untuk memperoleh SPI diajukan kepada Direktur Jenderal dan sekurangkurangnya memuat : $a$. Identitas pemohon; $b$. Jumlah SPI yang dimohonkan; c. Alat penangkap ikan yang akan digunakan dan daerah penangkapan serta pelabuhan pangkalan; d. Asal-usul kapal.

\section{3) Pola Lisensi}

Pasa 1 angka 3 Kepmen KP No. 60 Tahun 2001 mendefiniskan lisensi adalah kesempatan yang diberikan kepada orang atau badan hukum asing untuk menggunakan kapal perikanan miliknya menangkap ikan di ZEEI dalam jangka waktu tertentu, dimana penerima kesempatan wajib menunjuk perusahaan perikanan sebagai agen atau perwakilannya di Indonesia dan pemberian kesempatan tersebut merupakan pelaksanaan perjanjian di bidang perikanan tangkap antara Pemerintah Negara Republik Indonesia dengan pemerintah negara dari penerima kesempatan.

Untuk menerapkan persyaratanpersyaratan dan kondisi-kondisi bagi lisensi, otorisasi atau izin yang memadai untuk memenuhi setiap kewajiban sub regional, regional atau global dari Negara bendera Hak yang diberikan berdasarkan Pasal 69 dan 70 Konvensi Hukum Laut 1982 untuk mengekploitasi sumber kekayaan hayati tidak boleh dialihkan baik secara langsung atau tidak langsung kepada Negara ketiga atau warganegaranya dengan cara sewa atau perizinan, dengan mengadakan usaha patungan atau dengan cara lain apapun yang mempunyai akibat pengalihan demikian, kecuali disetujui secara lain oleh negara-negara yang berkepentingan. ${ }^{35}$ Pemberian lisensi kepada pengusaha perikanan nasional yang hanya menjadi agen bagi pengusaha asing

35 Badan Pembinaan Hukum Nasional, 2009, Analisis dan Evaluasi Hukum Tentang Pengadilan Perikanan, Disusun Oleh Tim Kerja Di Bawah Pimpinan: Rudy Satriyo Mukantardjo, Jakarta, Departemen Hukum dan Hak Asasi Manusia RI, hlm. 36. 
untuk menangkap ikan di ZEEI merupakan suatu hal yang beresiko terhadap keberlanjutan SDI. Dalam mekanisme ini tidak ada instrumen pendukung yang mengefektifkan kebijakan pada tataran implementatif baik berupa insentif maupun disinsentif. 36

Penggunaan kapal perikanan dengan cara lisensi dilakukan dengan memberi kesempatan kepada orang atau badan hukum asing untuk menggunakan kapalnya menangkap ikan di ZEEI. Pemberian kesempatan kepada orang atau badan hukum asing untuk menangkap ikan di ZEEI dengan cara lisensi dilakukan dengan syarat: a. telah diadakan perjanjian bilateral antara Pemerintah RI dengan Pemerintah Negara Asing asal orang atau badan hukum asing; b. kebangsaan kapal perikanan yang dipergunakan sama dengan kebangsaan orang atau badan hukum asing; c. terdapat surplus Jumlah Tangkapan yang diperbolehkan (JTB) yang akan ditetapkan tersendiri dengan Keputusan Menteri.

Orang atau badan hukum asing yang akan melakukan penangkapan ikan di ZEEI dengan cara lisensi, harus terlebih dahulu memperoleh Alokasi Penangkapan Ikan Asing (APIA) dari Direktur Jenderal. APIA dapat disampaikan permohonannya apabila telah memenuhi syarat untuk Pemberian kesempatan kepada orang atau badan hukum asing untuk menangkap ikan di ZEEI dengan cara lisensi. Surat permohonan untuk memperoleh APIA disampaikan kepada Direktur Jenderal dan sekurang-kurangnya memuat: a. Identitas pemohon; b. Jumlah alokasi kapal berdasarkan alat tangkap dan ukuran; dan c. Daerah penangkapan. APIA diterbitkan dan diberikan kepada pemohon jika telah memenuhi persyaratan dan berlaku sesuai dengan jangka waktu berlakunya perjanjian bilateral. Kapal perikanan berbendera asing yang akan digunakan oleh orang atau badan hukum asing untuk menangkap ikan di ZEEI wajib dilengkapi SPI. Permohonan untuk memperoleh SPI disampaikan paling lambat satu tahun terhitung sejak tanggal penerbitan APIA.

\section{SIMPULAN DAN SARAN}

\section{Simpulan}

Pengaturan usaha perikanan tangkap terpadu ZEEI dalam sistem bisnis perikanan merupakan bentuk usaha yang dilakukan dari penangkapan and pengangkutan (pra produksi), pengolahan (produksi) dan pemasaran (pasca produksi) dalam satu mata rantai bisnis perikanan. Industri perikanan terpadu ZEEI dapat dipadukan dengan kawasan berikat dan minapolitan. Pola hukum yang dalam industri ini ialah pola-kerjasama, pola sewa beli dan pola linsensi.

\footnotetext{
36 Tridoyo Kusumastanto, Loc.cit.
} 


\section{Saran}

Aspek hukum penanaman modal usaha perikanan tangkap terpadu ZEEI dalam kawasan berikat minapolitan dapat segera direalisasikan menjadi skala prioritas tinggi pada skala nasional untuk direncanakan, diregulasikan dan dipromosikan kepada investor asing dan nasional. Pembangunannya lebih ditujukan pada kawasan pesisir-pesisir di Kawasan Indonesia Timur sehingga terwujudkan kesejahteraan masyarakat dan industri perikanan yang berbasis kedaulatan (sovereignty), keberlanjutan (sustainability) dan kemakmuran (prosperity).

\section{DAFTAR PUSTAKA}

Badan Pembinaan Hukum Nasional, 1993-1994, Laporan Penelitian Tentang Aspek-Aspek Hukum Pengelolaan Perikanan di Perairan Nasional Zona Ekonomi Eksklusif Indonesia, Dibawah Pimpinan: H.A.S. Natabaya, Jakarta : Badan Pembinaan Hukum Nasional Departemen Kehakiman.

, 2009, Analisis dan Evaluasi Hukum Tentang Pengadilan Perikanan, Disusun Oleh Tim Kerja Di Bawah Pimpinan: Rudy Satriyo Mukantardjo, Jakarta, Departemen Hukum dan Hak Asasi Manusia RI.

\footnotetext{
------, 2012, Pengkajian Hukum Tentang Perlindungan Nelayan Tradisional Dalam Pengelolaan Sumber Daya Kelautan, Disusun Oleh Tim Di bawah Pimpinan Dr. Arif Satria, S.P., M.Si., Editor Theodrik Simorangkir, Jakarta : Badan Pembinaan Hukum Nasional Kementerian Hukum dan Hak Asasi Manusia RI.
}

Thomas Farole, et.al, 2011,Special Economic Zones Progress, Emerging Challenges, and Future Directions, World Bank: Washington DC.

Henriksen, Tore et.al, 2006, Law and Politics in Ocean Governance The UN Fish Stocks Agreement and Regional Fisheries Management Regimes, Martinus Nijhoff Publishers : Leiden / Boston.

Kementerian Kelautan dan Perikanan Republik Indonesia (KKPRI), 2010, Pokok Kelautan dan Perikanan Tahun 2010, Jakarta : Pusat Statistik Koordinasi dan Penanaman Modal Kemennterian Dalam Negeri Lembaga IImu Pengetahuan Indonesia.

Kraska, James, 2011, Maritime Power and The Law of The Sea Expeditionary Operations In World Politics, New York : Oxford University Press.

Marzuki, Peter Mahmud, 2013, Penelitian Hukum, Edisi Revisi, Jakarta : Kencana Prenada Media Group.

Erman Rajagukguk, 1985, Indonesianisasi Saham, Jakarta : Bina Aksara.

Ramlan, 2015, Konsep Hukum Tata Kelola Perikanan Perlindungan Hukum Industri Perikanan dari Penanaman Modal Asing di Indonesia, Malang : Setara Press.

Soesilo, Indroyono dan Budiman, 2006, IPTEK Menguak Laut Indonesia, Bogor : Sarana Komunikasi Utama (SKU).

Solihin, Akhmad, 2010, Politik Hukum Kelautan \& Perikanan Isu, Permasalahan, dan Telaah Kritis Kebijakan, Bandung : Nuasa Aulia. 
Sornarajah, M., 2010, The International Law On Foreign Investment, Third Edition, New York : Cambridge University Press.

Subagyo, P. Joko 2009, Hukum Laut Indonesia, Rineka Cipta: Jakarta.

Tribawono, H. Djoko 2013, Hukum Perikanan Indonesia, Edisi Revisi, Bandung : Citra Aditya Bhakti.

\section{J URNAL DAN ARTIKEL}

Dina Sunyowati, Dampak Kegiatan IUU-Fishing Di Indonesia, Disampaikan pada Seminar Nasional "Peran dan Upaya Penegak Hukum dan Pemangku Kepentingan Dalam Penanganan dan Pemberantasan IUU Fishing di Wilayah Perbatasan Indonesia". Kerjasama Kementerian Luar Negeri Republik Indonesia dengan Universitas Airlangga Surabaya, 22 September 2014.

\section{PERATURAN PERUNDANG-UNDANGAN}

Konvensi Hukum Laut 1982

Undang-Undang No. 31 Tahun 2004 Tentang Perikanan sebagaimana diubah oleh UU No. 45 Tahun 2009 (UUP).

Undang-Undang No. 5 Tahun 1983 Tentang Zona Ekonomi Eksklusif Indonesia

Peraturan Menteri Kelautan dan Perikanan Republik Indonesia No.Per.30/Men/2012 Tentang Usaha Perikanan Tangkap Di Wilayah Pengelolaan Perikanan Negara Republik Indonesia.

Peraturan Menteri Kelautan dan Perikanan Republik Indonesia No. 12/Men/2010 tentang Minipolitan.
Keputusan Menteri Kelautan dan Perikanan Nomor : KEP.60/MEN/2001 Tentang Penataan Penggunaan Kapal Perikanan Di Zona Ekonomi Eksklusif Indonesia

\section{INTERNET}

Aji Sularso, http://ajisularso.com/industri-perikananberbasis-clusterl, diakses 7 November 2015.

Badan Koordinasi Penanan Modal (BKPM), Fisheries Industry at Glance, lihat website: www.bkpm.go.id, diakses 11 Agustus 2015.

Kiara Bakal Kawal Komitmen Kelautan Presiden Jokowi, http://sumbar.antaranews.com/, diakses 11 Agustus 1945.

http://www.kompasiana.com/rokhmin/pengembanga n-kawasan-pertumbuhan-ekonomi-baruberbasis-kelautan-di-mamujuutara 54f96a07a3331177578b45c1, diakses 7 November 2015.

http://bappenas.go.id/files/5214/4401/3139/8 Bab

6 Isu Strategis Dan Permasalahannya.pdf 6-7, diakses 12 November 2015.

Rokhmin Dahuri, Dibutuhkan Platform Pembangunan Ekonomi yang Berpihak ke Laut, http://perpustakaan.bappenaas.go.id, diakses 13 November 2015.

Tridoyo Kusumastanto, Pemberdayaan Sumberdaya Kelautan, Perikanan Dan Perhubungan Laut Dalam Abad XXI, http://www.lfip.org/english/pdf, diakses 13 November 2015. 